\title{
Granting of Loans Cooperative to Members who Affected by Flood (Study in KSP Forma Branch of Cirebon)
}

\author{
Mangirim Limbong ${ }^{1}$ and Lathifah Hanim $^{2}$
}

\begin{abstract}
In this research using normative juridical approach reviewing and view and analyze problems based on the principles and the principles of law. Once we examine Cooperative Forma, found the research to solve the problem, namely (1) Cooperative Forma will provide loans conditional on the existence of collateral both objects move or do not move the location of the object collateral is never experienced flooding or close to the river, (2) Cooperative Forma will provide relief penalties and interest for the members of the flooded rice fields or fields that can to repay the loan.

Keywords: Cooperatives; Loans; Jams; Natural Factors.
\end{abstract}

\section{Introduction}

Act of 1945 amendment to $V$ in particular Article 33 paragraph (1) states that the Indonesian economy is structured as a joint venture based on family principles. Further explanation of Article 33 between that the prosperity of society thatpreferably not the prosperity of individuals and build the appropriate company is cooperative. Explanation article 33 puts good cooperative in its capacity as a pillar of the national economy as well as an integral part of national economic order. By paying attention to the position of cooperatives as mentioned above, the role of cooperatives is important in growing and developing the economic potential of people as well as in realizing economic democracy lives that have democratic characteristics, togetherness, family, and openness. ${ }^{3}$ In accordance with the foregoing, the Indonesian nation has made development to achieve national goals, which is to realize a just and prosperous society materially and spiritually based on Pancasila and the Constitution of 1945.

Efforts have been made by the government that one of them is to improve the lives of people of Indonesia, especially in social and economic fields by providing loans to people who need additional capital. In addition to the Bank or other institutions such as procurement, cooperation as the economic lifeblood of the nation of Indonesia. ${ }^{4}$ The cooperative has always acted to protect their weak economic communities that are members of the cooperative public cooperativenya.Secara understood as a voluntary association of people who unite themselves to fight for the improvement of their economic welfare in a democratic company. ${ }^{5}$ "The cooperative is a legal entity established by individuals or legal entities cooperatives, with the separation of the wealth of its members as capital to run the business, which meet the aspirations and needs of economic, social and cultural rights in accordance with the co-operative

\footnotetext{
${ }^{1}$ Student Masters (S-2) of Law Faculty of Law UNISSULA Semarang E-mail limbongmangirim@yahoo.co.id

${ }^{2}$ Lecture of Faculty of Law UNISSULA Semarang,

${ }^{3}$ Bernhard Limbong 2010 Pengusaha Koperasi memperkokoh Fondasi Ekonomi Rakyat Jakarta p. 80

${ }^{4}$ G. Kartasapoetra dan A.G Kartasanoetra dan kawan 2007 Koperasi Indonesia yang Berdasarkan Pancasila dan UUD 1945 Jakarta p. 11

${ }^{5}$ Revrisond Baswir 2005 Koperasi Indonesia Yogyakarta p. 2
} 
values and principles".

In line with that in the Cooperative Law implanted ideas towards the development of cooperative management in professional. Based on the foregoing, the Act is structured with a view to clarify and reinforce the identity, the purpose of the position, role, management, keusahaan and cooperative capital as well as development cooperation, so as to better guarantee the formation of cooperative life as mandated by Article 33 of the UUD 1945 . $^{6}$

Today cooperatives continue expanding in its efforts to keep abreast of human needs are not limited. The field of cooperative efforts is felt increasingly increasingly needed by society is the issue of savings and loan, one of the tasks of Indonesian cooperatives are providing loans to its members. ${ }^{7}$

Likewise with Forma Cooperatives in conducting business activities promote the common welfare, conduct activities in the field of savings and loans, provide welfare services so that members can secure and facilitate subsistence nature its members. As with savings and credit cooperatives or credit unions, the main objective of this cooperative operation is as an alternative means in terms of borrowing money or credit. Other than the cooperative also seeks to avoid members of moneylenders who provide loans at high interest rates, without any clear agreement that could aggravate the economic situation of its members. In practice, before providing credit, the creditor (Cooperative) usually do some research first to character, Capacity (ability). ${ }^{8}$ But lately KSP forma experiencing congestion caused by natural disasters such as flooding in the area of Brebes-Cirebon, with many rice fields were flooded where productivity namely onions, of course, the farmers a lot to lose because they can not harvest the onions and of course money borrowed from cooperative difficult for farmers to restore to the cooperative, so therefore, the cooperative provides policy, the cooperative will provide loans to its members, especially the onion farmers if the location of his land or the land is not flooded or not often hit by flooding, although it may be very difficult all because the rainfall in 2018 the rainfall is still great, but this is the situation and the need to provide a solution.

Based on the description of the above background, the issues to be discussed as follows: How does the process of implementation of cooperative lending to its members due to flooding in KSP Forma Branch of Cirebon? What are the constraints and solutions in the implementation of cooperative lending to members who affected by floods in KSP Forma Branch of Cirebon?

\section{Results and Discussion}

\subsection{Implementation Lending cooperative to its members due to flooding in KSP Forma Branch of Cirebon}

On the lending process at KSP Forma, the cooperative needs to assess the ability of members of the Cooperative to repay the loan or pay off the loan in a timely manner. The application of the principle of prudence in lending cooperative for the

\footnotetext{
${ }^{6}$ Kartasapoetra G. and A. G Kartasanoetra et al Ibid p. 11

${ }^{7}$ Partadiredja Atje 2007 Manajemen Koperasi Jakarta p. 3

${ }^{8}$ Muhammad Djumliana 2006 Hukum Perbankan di Indonesia Bandung p. 394
} 
purpose of maintaining financial system stability and protect cooperatives and cooperative members as depositors, so KSP Forma expected to continue to remain in a healthy condition and able to meet its obligations to members of the cooperative.

KSP Forma asserted that in providing loans and conduct other businesses, cooperatives obliged to follow in ways that do not harm the interests of the cooperative itself and the members of the cooperative who entrust their funds to Cooperative. So in disbursing a loan to a member of the cooperative, Cooperative should pay attention to the security aspects for the return of the loan. After receiving a loan cooperatives need to monitor the use of the loan funds, as well as the ability and adherence to the cooperative members in fulfilling their obligations. To avoid problems in repayment of a loan then in the agreement stated that the Cooperative always ask for a guarantee that is useful to the security of a cooperative loan funds are released. Guarantees can be considered as a means to pursue a prevention or a preventive measure in a very risky loan agreement. KSP Forma generally think and act in lending after assessing the requirements of $5 \mathrm{C}$ owned by debtor, namely a prospective borrower (cooperative members) granted their petition if you have any collateral or guarantees (collateral), which exceeds the amount of the loan. The amount of money loans will not exceed $70 \%$ of the value of the collateral. At the time the loan is obtained, the cooperative members must submit proof of ownership of collateral to the Cooperative. When there is congestion in the loan, the collateral used in payment of debts in arrears or mortgage will be sold to a third party for payment. Cooperative will provide loans to prospective members of the cooperative with capital, although only slightly and not to members of the cooperative who have no capital at all. Loans creditor serves as additional capital to facilitate productive activities so that these activities more effective and efficient. Cooperative members should have some funds allocated specifically as initial capital for the productive activities.

Capabilities (capacities) member cooperatives in the use and return the loan will be assessed lenders who will lend. Cooperative assess the candidate's ability to analyze the feasibility of cooperative members proposal by members of the cooperative when asking proposal. When cooperative members applying for loans to enterprises, cooperative members also assessed the ability of the trip member cooperative efforts that have been done so far is based on financial statements that members of the cooperative. Cooperative also will give review properties (caracters) member cooperative in managing money, especially honesty, discipline and habit in managing cash flow. Passbook or statements that members of the cooperative have become a source of information for the Cooperative in properties of the cooperative members in managing money.

The last thing that is not less important is the consideration of cooperation in economic conditions that are a good economic. Condition caused lenders to give a lot of convenience in providing loans. In other side, difficult economic conditions resulted in a cooperative rather strict in lending to the cooperative. Eventhough member of legislation guaranteeing freedom of contract for the parties, but in practice, the making of the loan agreement, the position of the parties is generally unbalanced position of members of the cooperative which is weaker than the position of the borrower as the owner of the funds and collateral. In granting the 
loan certainly there is congestion that resolved by (1)gave the warning letter first (SP1) (2) to give a second warning letter (SP2) (3) gives a warning letter first (4) gave the second warning letter if the first warning was ignored, with copies counsel cooperative (5) improve the legal status binding guarantees (6) somasi (7) filed a petition to the district court and the execution of guarantees.

In providing loans, the Cooperative shall have confidence in the ability and willingness to repay their debts cooperative members in accordance with the promised. Every loan application submitted by members of the cooperative, always consider matters relating to the internal state of the cooperative and state cooperative members (borrowers), but in 2018 the Cooperative experiencing congestion caused by the members do not return the money belonging to cooperatives which in result fields and a field of onions being flooded, but cooperative will continue to provide loans with internal memperhatikankeadaan and able to provide funding for the loan applicant, then the next step is to consider loan applications submitted by member cooperatives, things that need to be considered in terms of lending to cooperatives are: ${ }^{9}$

- Private borrowers

- His efforts

- The ability and willingness to repay the loan and other things

- loan guarantees

Basically KSP Forma willing to give loans but with full-loaded, such as the guarantee of moving objects and unmovable objects. For preventive security issues, the Cooperative Forma will ask for collateral for loans disbursed to the applicant. Goods that are used as collateral only include: ${ }^{10}$

- Chattels which by their nature goods can move or be movedhanded over, for example the motor. Stir goods as collateral straps are fiduciary, that is used as collateral is not delivered, but delivered only a power of attorney or ownership of goods, such as reg.

- Immovable goods are goods which by their nature are not fixed or mobile, such as land, yard etc, certified SHM (proprietary) or HGB (building rights), KSP forma give policies to immovable that will be made bail, then the guarantee is not around the area often floods or near the river, then the guarantee does not meet syrat to be given a loan.

\subsection{Constraints and solutions in the implementation of cooperative lending to members of floods in Forma Cooperative Branch of Cirebon}

Constraints in lending that is due to several factors, such as:

\subsubsection{Social factors}

In the implementation of lending in KSP Forma Branch of Cirebon conducted through the steps were very helpful members of the Cooperative and can overcome the problems arising for the board to approve the loan application or not. While the

\footnotetext{
${ }^{9}$ Interview with Sri Rahayu Nip: 023/97/15 as staff Multipurpose Cooperative Forma Branch of Cirebon Enterprises dated March 252018

${ }^{10}$ Interview with Lola S Nip: $021 / 96 / 15$ as staff Forma Business Multipurpose Cooperative Administration Branch of Cirebon dated March 252018
} 
provision or consideration in the execution of the loan agreement based on substantial savings of cooperative members and the amount of salary or income members who will perform the loan agreement. Only in executing loan agreements are sometimes not in accordance with existing rules such lending will be granted if the member has to pay off their loans, lending is given to members who still have unfinished loans repaid. Social factors have a great effect to KSP Forma, such as (a) the bankruptcy of the borrower enterprises (b) Divorce in the borrower; and (c) The $3^{\text {rd }}$ parties such as NGOs, authorities and institutions Person other that intervene, means the borrower asking for help parties to 3 without concern on promised default settlement had been agreed.

\subsubsection{Natural factors}

In the 2018's, rainfall Cirebon region is very high, in part many of the members of the cooperative are onion farmers certainly influence the season very major role, since fields and rice paddies from farmers experienced flooding, the farmers too late and no or less in terms of return money to cooperatives, cooperative so the circulation also be stalled, but the cooperative is always seeking communication with its members, unable to pay are also important still is no good faith by providing solution on member bankruptcies, namely :

- KSP Forma Party will provide relief payments to members of the cooperative when his business failed to provide a reduction of fines and give wide time of payment.

- KSP Forma party will call and renegotiate the agreements that have been agreed by cooperative members who borrow the stalled payment by way of deliberation by a family in the settlement of arrears or default done without involving borrowers as third member.

- KSP Forma party will call and went through a divorce cooperative members to resolve problems that were jammed or wanpretasi loan with amicable way without harm both parties.

\section{Closing}

\subsection{Conclusion}

- KSP Forma generally think and act in lending after assessing the requirements of $5 \mathrm{C}$ owned by debtor, ie a prospective borrower (cooperative members) granted their petition if you have any collateral or guarantees (collateral), which exceeds the amount of the loan. Capital although only slightly and not to members of the cooperative who have no capital at all, Capability (capacities) member cooperatives in the use and return the loan will be assessed lenders will lend, KSP Forma will also assess the properties (caracters) member cooperative in managing money, the last thing that is not less important is the consideration of cooperation in economic conditions at hand.

- Constraints in lending that is due to several factors, such as (1) Social factors, (2) Natural Factors. While KSP Forma provide solutions to members of bankruptcies, namely (a) Forma KSP Party will provide relief payments to members of the cooperative when his business failed to provide a reduction of fines and give 
kelonggoran time of payment. (B) The KSP Forma will call and renegotiate the agreements that have disepakti with cooperative members who borrow the stalled payment by way of deliberation by a family in the settlement of arrears or default done without involving borrowers as a third member.

\subsection{Suggestion}

Based on the above conclusions, the authors suggest, as follows:

- For the Government, so pay attention and care of irrigation systems, rivers and water reservoirs, in order to minimize flooding in the rainy season.

- For cooperatives, so meticulous in giving loans to the cooperative's members mainly see the capabilities and conditions of the location of collateral

- For members of KSP Forma so meticulous in taking into account the weather and climate for farmers growing natural onions. Especially, do not lend to the areas prone to flooding this as an attempt to minimize losses.

\section{Bibliography}

[1] Bernhard Limbong 2010, Pengusaha Koperasi memperkokoh Fondasi Ekonomi Rakyat Jakarta.

[2] G. Kartasapoetra dan A.G Kartasanoetra dan kawan 2007 Koperasi Indonesia yang Berdasarkan Pancasila dan UUD 1945 Jakarta.

[3] Muhammad Djumliana 2006 Hukum Perbankan di Indonesia Bandung.

[4] Revrisond Baswir 2005 Koperasi Indonesia Yogyakarta.

[5] Partadiredja Atje 2007 Manajemen Koperasi Jakarta.

[6] Constitution of the Republic of Indonesia of 1945

[7] Act No. 25 of 1992 concerning Cooperatives

\section{Interview}

[1] Interview with Sri Rahayu Nip: 023/97/15 as staff Multipurpose Cooperative Forma Branch of Cirebon Enterprises dated March 25, 2018

[2] Interview with Lola, S Nip: $021 / 96 / 15$ as staff Forma Business Multipurpose Cooperative Administration Branch of Cirebon dated March 25, 2018 